\title{
Loss of muscle strength in community-dwelling elderly is associated with type 2 diabetes
}

\author{
Valéria Pagotto ${ }^{*}$, Daniella Moreira Dias, Kassyla Ferreira dos Santos, Joyce Gabriella Menezes Silva, \\ Wanessa Freitas Silva, Erika Aparecida da Silveira \\ From 20th Brazilian Diabetes Society Congress \\ Porto Alegre, Brazil. 11-18 November 2015
}

\section{Background}

A loss of skeletal muscle mass and strength is frequently observed in older adults. Persons with diabetes have accelerated muscle and strength loss, but the relationship of hyperglycemia to declines in muscle function has not been explored yet.

\section{Objective}

To investigate the relationship between type 2 diabetes and low muscle mass and strength in community-dwelling elderly.

\section{Materials and methods}

Data was obtained in the Elderly Project/Goiânia, a cross-sectional study comprising 132 community dwelling elderly ( $>60$ yrs.) of Goiânia, Goiás, Brazil. Muscle mass was estimated by standard methods by using dual$\mathrm{x}$-ray-absortiometry (DXA) and was determined by the skeletal muscle mass index (SMI). Muscle strength was determined by Hand grip strength (hand-GS) with a dynamometer on dominant hand. Diabetes diagnose was identified by self-report or use of hypoglycemic agents. Analyses were performed in STATA 12.0. We calculated the prevalence and the difference ratio was evaluated by the Pearson chi-square test $(\mathrm{p}<0.05)$. This study was approved by the Research Ethics Committee of UFG.

\section{Results}

Of the 132 elderly studied, $60.9 \%$ were women, mean age 70.1 yrs. $( \pm 6.63)$ and mean BMI of $26.7 \mathrm{~kg} / \mathrm{m} 2$ $( \pm 26.7)$. The mean SMI was $6.69 \mathrm{~kg} / \mathrm{m}^{2}$, and $7.50 \mathrm{~kg} / \mathrm{m}^{2}$ among men and $6.16 \mathrm{~kg} / \mathrm{m}^{2}$ in women $(\mathrm{p}=0.001)$. The average FPP was $22.8 \mathrm{kgf}( \pm 8.38)$, and $29,9 \mathrm{kgf}$ between

\footnotetext{
* Correspondence: valeriapagotto@gmail.com
} Universidade Federal de Goiás, Goiânia, Brazil men and $18,1 \mathrm{kgf}$ in women $(\mathrm{p}=0.001)$. The prevalence of diabetes was $18.5 \%$, with higher prevalence in young people aged, 60-69 yrs. (21.7\%). Low muscle strength was observed in $25 \%$ of diabetic patients $(\mathrm{p}=0.05)$ and low muscle mass in $8.3 \%$ of diabetics with no statistically significant differences $(\mathrm{p}>0.05)$.

\section{Conclusions}

Type 2 diabetes is associated with loss of skeletal muscle strength in community-dwelling older adults. Future studies should explore if better glycemic control can preserve muscle strength in diabetes.

Published: 11 November 2015

doi:10.1186/1758-5996-7-S1-A39

Cite this article as: Pagotto et al:: Loss of muscle strength in

community-dwelling elderly is associated with type 2 diabetes.

Diabetology \& Metabolic Syndrome 2015 7(Suppl 1):A39.

Submit your next manuscript to BioMed Central and take full advantage of:

- Convenient online submission

- Thorough peer review

- No space constraints or color figure charges

- Immediate publication on acceptance

- Inclusion in PubMed, CAS, Scopus and Google Scholar

- Research which is freely available for redistribution

Submit your manuscript at www.biomedcentral.com/submit
() Biomed Central 